\title{
HUBUNGAN LAMA PENGGUNAAN SUNTIKAN TIGA BULAN DENGAN KENAIKAN BERAT BADAN DI RUMAH BERSALIN MARIANA KUBU RAYA TAHUN 2016
}

\author{
Elise Putri ${ }^{1}$, Telly Katharina ${ }^{2}$
}

Akademi Kebidanan Panca Bhakti Pontianak

Email korespondensi: akbidpbpontianak@gmail.com

\begin{abstract}
Abstrak
Depo medrosiprogesteron asetat (DMPA) yaitu mengandung $150 \mathrm{mg}$ DMPA, yang diberikan setiap 3 bulan dengan cara disuntik intramuscular (didaerah bokong). Wanita yang menggubakan kontrasepsi suntik 3 bulan rata-rata mengalami kenaikan berat badan sebanyak 5,5 kg dan mengalami peningkatan lemak tubuh sebanyak 3,4\% dalam waktu 3 tahun pemakaian. Tujuan penelitian untuk mengetahui hubungan lama penggunaan suntikan tiga bulan dengan kenaikan berat badan di rumah bersalin Mariana kubu raya tahun 2016. Desain penelitian deskriptif korelasi dengan pendekatan cross sectional dan instrument yang digunakan dengan menggunakan lembar ceklist populasi sebanyak 173 orang yang menggunakan alat kontrasepsi suntik 3 bulan, sampel sebanyak 34 orang dan tehnik sampling menggunakan purposive sampling. Hasil penelitian didapatkan 19 orang $(55,89 \%)$ menggunakan kb suntik selama $>6$ bulan - 3 tahun, sebanyak 31 orang $(91,18 \%)$ mengalami kenaikan berat badan, dan ada hubungan antara lama penggunaan suntikan tiga bulan dengan kenaikan berat badan. Penelitian ini dapat digunakan untuk meningkatkan pelayanan dalam memberikan konseling atau informasi terhadap pelayanan Keluarga Berencana (KB) sehingga para akseptor KB dapat memperoleh informasi yang cukup dan baik tentang Keluarga Berencana khususnya tentang KB suntikan 3 bulan.
\end{abstract}

Kata kunci: suntik 3 bulan, kenaikan berat badan

\section{Pendahuluan}

Depo medrosiprogesteron asetat (DMPA) yaitu mengandung $150 \mathrm{mg}$ DMPA, yang diberikan setiap 3 bulan dengan cara disuntik intramuscular (didaerah bokong). Efek samping yang bias ditimbulkan dari depo medrosiprogesteron asetat (DMPA) yaitu gangguan siklus haid, amenore (tidak haid), spotting atau metrorargia (perdarahan bercak atau menetes), depresi, keputihan, jerawat, rambut rontok, pusing atau sakit kepala mual dan muntah, perubahan libido atau dorongan seksual, dan tidak kalah pentingnya yaitu terjadi perubahan atau peningkatan berat badan (Irianto, 2014).

Berdasarkan data dari badan kependudukan keluarga berencana nasional (BKKBN 2010) diketahui, bahwa di Indonesia

\footnotetext{
${ }^{1}$ Dosen Akademi Kebidanan Panca Bhakti Pontianak

${ }^{2}$ Dosen Akademi Kebidanan Panca Bhakti Pontianak
}

yang menggunakan metode kontrasepsi dengan suntik sebanyak $58,25 \%$, pil sebanyak $24,37 \%$, intra uterine devices (IUD) sebanyak 7,23\%, implant sebanyak $4,16 \%$, metode operatif wanita (MOW) sebanyak 3,13\%, metode operatif pria (MOP) sebanyak 1,03\%, kondom sebanyak $0,68 \%$, intravaginal tissue sebanyak $0,11 \%$ dan metode tradisional sebanyak $1,04 \%$. Jumlah pasangan usia subur (PUS) berdasarkan data profil kesehatan kabupaten atau kota tahun 2011 sebesar 843.183 dengan jumlah peserta aktif sebesar 546.473 (64.8\%) dan peserta KB baru sebesar 108.172 (12,8\%). Pada tahun 2011 di Kalimantan Barat, penggunaan suntik sebagai alat menunda kehamilan banyak dipilih oleh pasangan usia subur (PUS) yaitu sebanyak 50,3\%, kemudian 
diikuti oleh penggunaan pil sebanyak 38,9\%. Sedangkan penggunaan MOP dan MOW merupakan alat kontrasepsi yang paling sedikit diminati oleh PUS untuk menunda kehamilannya yaitu masing-masing sebesar 1,3\% untuk MOWdan 0,3\% untuk MOP.

Berdasarkan data Badan Pusat Statistik Provinsi Kalimantan Barat tahun 2013, kKabupaten Kubu Raya berada di peringkat kedua jumlah akseptor aktif kontrasepsi suntik terbanyak. Data Profil Puskesmas Sungai Kakap menunjukkan akseptor suntikan aktif terbanyak di Puskesmas dan desa Puskesmas Sungai Kakap sebesar 638 orang $(42,1 \%)$ pada tahun 2013, dengan proporsi akseptor aktif suntikan progestin lebih banyak $(31,6 \%)$ daripada suntikan kombinasi $(10,5 \%)$.

Berdasarkan studi pendahuluan yang dilakukan peneliti di Rumah Bersalin Mariana pada bulan Maret 2016, diperoleh data rekam medic dari bulan Januari hingga Desember tahun 2015, terdapat 278 akseptor KB suntik 3 bulan dan berdasarkan hasil wawancara yang peneliti lakukan kepada 5 akspetor yang melakukan kunjungan ulang serta melihat dari kartu kunjungan ulang akspetor $\mathrm{KB}$ dan hasilnya 3 orang mengalami kenaikan berat badan dan 2 lainnya tidak mengalami kenaikan berat badan hal ini menujukkan bahwa pada akseptor yang menggunakan KB suntik 3 bulan banyak yang mengalami kenaikan berat badan.

Lama penggunaan $\mathrm{KB}$ sutikan 3 bulan biasanya juga mengacu pada perubahan atau peningkatan berat badan akseptor KB suntik 3 bulan, sehingga dalam hal ini peneliti ingin mengetahui hubungan lama penggunaan suntikan 3 bulan dengan kenaikan berat badan pada akspetor KB suntik 3 bulan. Terlebih juga berdasarkan studi pendahuluan yang telah dilakukan di Rumah Bersalin Mariana yaitu 3 dari 5 akseptor mengeluh telah mengalami perubahan atau peningkatan berat badannya.

\section{Metode}

Desain penelitian deskriptif korelasi dengan pendekatan cross sectional dan instrument yang digunakan dengan menggunakan lembar ceklist populasi sebanyak 173 orang yang menggunakan alat kontrasepsi suntik 3 bulan, sampel sebanyak 34 orang dan tehnik sampling menggunakan purposive sampling.

\section{Hasil dan Pembahasan}

Tabel 1 Karakteristik Responden

\begin{tabular}{lcc}
\hline \multicolumn{1}{c}{ Karakteristik } & N & Presentase \\
\hline Lama Penggunaan Suntikan 3 Bulan & 19 & \\
$>6$ bulan -3 tahun & 15 & 55,89 \\
$>3$ tahun & 31 & 44,11 \\
Kenaikan Berat Badan & 3 & 91,18 \\
$1-5 \mathrm{~kg}$ & & 8,82 \\
$>5 \mathrm{~kg}$ &
\end{tabular}

Berdasarkan tabel diatas didapatkan bahwa responden yang menggunakan suntikan 3 bulan > 6 bulan -3 tahun yaitu 19 orang
$(55,89 \%)$. Berdasarkan tabel diatas didapatkan bahwa hampir seluruh responden mengalami kenaikan berat badan yang $1-5 \mathrm{~kg}$ selama 
menggunakan suntikan 3 bulan yaitu 31 orang

$(91,18 \%)$.

Tabel 2 Hasil Analisis Bivariat

\begin{tabular}{lcccccc}
\hline \multirow{2}{*}{$\begin{array}{c}\text { Lama Penggunaan } \\
\text { Suntikan 3 Bulan }\end{array}$} & \multicolumn{4}{c}{ Kenaikan berat badan } & \multirow{2}{*}{ R hitung } & \multirow{2}{*}{ R tabel } \\
\cline { 2 - 5 } & $\mathrm{N}$ & $\%$ & $\mathrm{~N}$ & $\%$ & & \\
\hline$>6$ bulan -3 tahun & 18 & 52,92 & 1 & 2,94 & \multirow{2}{*}{0,40} & \multirow{2}{*}{0,399} \\
$>3$ tahun & 13 & 38,23 & 2 & 5,88 & & \\
\hline
\end{tabular}

Berdasarkan tabel diatas diperoleh bahwa responden yang menggunakan $\mathrm{KB}$ suntik 3 bulan, dengan lama pemakaian $>6$ bulan -3 tahun mengalami kenaikan berat badan $1-5 \mathrm{~kg}$ yaitu 18 orang $(52,94 \%)$ dan menggunakan KB suntik > 3 tahun mengalami kenaikan berat badan $>5 \mathrm{~kg}$ yaitu 2 orang $(5,88 \%)$.

Berdasarkan hasil perhitungan korelasi product moment diperoleh $\mathrm{r}$ hitung $=0,40$ dengan demikian dan juga berdasarkan pedoman memberikan interpretasi terhadap koefisien korelasi, tingkat koefisien korelasi diantara dua variabel yaitu lama penggunaan suntikan 3 bulan dengan kenaikan berat badan adalah sedang, jika dibandingkan dengan nilai $\mathrm{r}$ tabel dengan tingkat kesalahan ditetapkan 5\% (tingkat kepercayaan 95\%), dan $\mathrm{N}=34$ yaitu nilai $r$ tabel $=0,339$ dan diperoleh hasil ternyata nilai $r$ hitung $>\mathrm{r}$ tabel, artinya Ha diterima dan Ho ditolak. Jadi bisa ditarik kesimpulan bahwa ada hubungan lama penggunaan suntikan 3 bulan dengan kenaikan berat badan.

Berdasarkan hasil penelitian yang telah dilakukan terhadap 34 orang responden didapatkan bahwa sebagian dari responden, menggunakan suntikan 3 bulan didapatkan responden yang menggunakan suntik KB tiga bulan > 6 bulan -3 tahun yaitu 19 orang $(55,89 \%)$, dan sebagain dari responden menggunakan suntikan 3 bulan lebih dari 3 tahun yaitu 15 orang (44,11\%). Menurut Saifudin (2010) bahwa depo medroksiprogesteron asetat (DMPA) yaitu mengandung $150 \mathrm{mg}$ DMPA, yang diberikan setiap 3 bulan dengan cara di suntikkan secara intramuscular (di daerah bokong).

Penelitian Irianingsih (2011) tentang pengaruh penggunaan kontrasepsi suntikan terhadap peningkatan berat badan dan kenaikan tekanan darah pada akseptor KB di Puskesmas Kecamatan Sukodono Kabupaten Sragen. Didapatkan dari 34 akseptor yang menggunakan KB suntik 3 bulan burang dari 1 tahun dan 36 akspetor yang menggunakan KB suntik3 bulan lebih dari 1 tahun. Hasil didapatkan 41 responden dengan peningkatan berat badan dan 29 responden tidak mengalami peningkatan berat badan, jadi akseptor yang menggunakan kontrasepsi suntik 3 bulan lebih dari 1 tahun lebih beresiko mengalami peningkatan berat badan.

Dalam jurnal Griya Husada (2014) dengan judul "gambaran kejadian peningkatan berat badan pada akseptor KB suntik 3 bulan berdasarkan lama pemakaian kontrasepsi diperoleh hasil akseptor KB suntik 3 bulan yang lama pemakaiannya lebih dari 1 tahun mayoritas mengalami kenaikan berat badan (89,72\%), di banding dengan akseptor yang memakai KB suntik 3 bulan kurang dari 1 tahun 
dengan berat badan stabil atau tetap $(42,86 \%)$, hal ini juga sejalan dengan penelitian yang dilakukan oleh peneliti yaitu dimana sebagian dari responden yang lama penggunaan suntikan 3 bulan, > 6 bulan - 3 tahun mengalami kenaikan berat badan $1-5 \mathrm{~kg}$ yaitu 18 orang $(52,94 \%)$.

Berkaitan dengan lama penggunaan suntikan 3 bulan, Beksinska et al (2001) di daam jurnal Pratiwi dengan judul "hubungan antara penggunaan kontrasepsi hormonal suntikan DMPA dengan peningkatan berat badan di puskesmas Lapai kota padang" dikatakan bahwa salah satu studi menemukan peningkatan nafsu makan yang dilaporkan sendiri oleh wanita yang menggunakan kontrasepsi DMPAsetelah 6 bulan. Hal ini dapat dihubungkan dengan kandungan padaDMPA yaitu hormone progesterone, yang dapat merangsang pusat pengendali nafsu makan dihipotalamus sehingga menyebabkan terjadinya peningkatan nafsu makan. Teori di dalam jurnal tersebut juga sesuai dengan yang dilakukan oleh peneliti bahwa yang mengalami kenaikan berat badan pada akseptor KB suntik 3 bulan yaitu yang telah menggunakan $\mathrm{KB}$ suntik 3 bulan setelah 6 bulan pemakaian.

Lama pemakaian adalah panjang waktu akseptor menggunakan kontrasepsi sampai berhentinya akseptor menggunakan kontrasepsi, dimana di dalam penelitian ini dan berdasarkan pengisian responden di dalam lembar check list yang telah diberikan oleh peneliti kepada responden menujukkan bahwa sebagian dari responden menggunakan suntikan
3 bulan $>6$ bulan -3 tahun yaitu 19 orang $(55,89 \%)$.

Berdasarkan hasil penelitian yang telah dilakukan terhadap 34 orang responden didapatkan bahwa hampir seluruh responden mengalami kenaikan berat badan yang $1-5 \mathrm{~kg}$ selama menggunakan sutikan 3 bulan yaitu sebanyak 31 orang $(91,18 \%)$ dan sangat sedikit dari responden mengalami kenaikan berat badan selama menggunakan suntikan 3 bulan yaitu $>5 \mathrm{~kg}$ berjunlah 3 orang $(8,28 \%)$.

Menurut Irianto (2014) umumnya pertambahan berat badan terhadap penggunaan suntikan 3 bulan tidak terlalu besar, bervariasi antara kurang dari $1 \mathrm{~kg}$ sampai $5 \mathrm{~kg}$ dalam tahun pertama. Penggunaan progesterone dapat meningkatkan nafsu makan, efek yang serupa dengan tingginya kadar progesterone dalam kehamilan. Bukti menunjukkan bahwa pertambahan berat badan ini adalah hasil dari peningkatan lemak dan bukan merupakan akibat sekunder dari proses anabolisme atau retensi cairan.

Berkaitan dengan penambahan berat badan selama penggunaan suntikan 3 bulan ini juga sesuai dengan penelitian Ekawati tahun 2010 dengan judul "pengaruh KB suntik terhadap peningkatan berat badan di BPS Siti Wonokarto Wonogiri" peneltian dilakukan terhadap 35 akseptor KB DMPA dan 35 akseptor KB bukan DMPA didapatkan hasil pada akseptor KB DMPA 24 responden mengalami kenaian berat badan dan 11 responden tidak mengalami kenaiakn berat badan. Pada akseptor KB bukan DMPA 17 responden mengalami kenaikan berat badan dan 
18 responden tidak mengalami kenaikan berat badan.

Hasil ini menunjukkan pada akseptor KB DMPA lebih banyak mengalami kenaikan berat badandari pada akseptor bukan KB DMPA. Penelitian tersebut juga sejalan dengan penelitian yang dilakukan oleh peneliti yaitu dimana hamper seluruh responden mengalami kenaikan berath badan 1-5 $\mathrm{kg}$ selama menggunakan suntikan 3 bulan yaitu sebanyak 31 orang $(91,18 \%)$.

Menurut Suparyanto (2010) perubahan berat badan adalah berubahnya ukuran berat, baik bertambah atau berkurang akibat dari konsumsi makanan yang diubah menjadi lemak dan disimpan di bawah kulit. Perubahan berat badan dibagi menjadi berat badan yang meningkat atau naik jika hasil penimbangan berat badan lebih besar dibandingkan dengan berat badan sebelumnya, dan berat badan menurun jika hasil penimbangan berat badan lebih rendah dibandingkan berat badan sebelumnya, dan berat badan menurun jika hasil penimbangan berat badan lebih rendah di bandingkan berat badan sebelumnya.

Menurut Hartanto (2014) dalam jurnal Griya Husada dengan judul " gambaran kejadian peningkatan berat badan pada akseptor KB suntik 3 bulan berdasarkan lama pemakaian KB suntik 3 bulan di BPM Anurul Soeprijadi Surabaya" factor-faktor yang menyebabkan peningkatan berat badan pada kontrasepsi progesterone diantaranya adalah pertambahan berat badan yang disebabkan oleh estrogen, mengakibatkan bertambahnya lemak sub cutan, terutama pada panggul, paha dan payudara, (2) nafsu makan yang bertambah daan makan banyak (efek anabolic disebabkan efek dari progestin), (3) intake kalori yang bertambah (4) kurang olahraga, perubahan dalam kebiasaan makan.

Berdasarkan hasil perhitungan korelasi product moment diperoleh $\mathrm{r}$ hitung $=0,40$ dengan demikian dan juga berdasarkan pedoman memberi interprentasi terhadap koefisien korelasi, tingkat koefisien korelasi diantara dua variabel yaitu lama penggunaan suntikan 3 bulan dengan kenaikan berat badan adalah sedang. Jika dibandingkan dengan nilai $r$ tabel dengan tingkat kesalahan ditetapkan 5\% (tingkat kepercayaan 95\%), dan $\mathrm{N}=34$ yaitu nilai $r$ tabel $=0,339$ dan diperoleh hasil ternyata nilai $r$ hitung $>r$ tabel, artinya Ha diterima dan Ho ditolak. Jadi bias ditarik kesimpulan bahwa ada hubungan lama penggunaan suntikan 3 bulan dengan kenaikan berat badan.

Lama penggunaan suntikan 3 bulan dengan kenaikan berat badan memiliki nilai korelasi positif yaitu 0,409 , besaran angka korelasi menunjukkan bahwa korelasi antara lama penggunaan suntikan 3 bulan dengan kenaikan berat badan yaitu "sedang $(0,40$ 0,599)”. Sementara nilai positif mengidentifikasikan pola hubungan antara lama penggunaan suntikan 3 bulan adalah searah yaitu semakin lama penggunaan suntikan 3 bulan semakin tinggi kenaikan berat badan. Perolehan $\mathrm{p}$ hitunh $=0,16<0,05$ yang menandakan bahwa hubungan yang terjadi adalah signifikan. Dari nilai korelasi didapatkan bahwa lama penggunaan suntikan 3 bulan 
mempengaruhi kenaikan berat badan sebesar 40\% di RB Mariana Kabupaten Kubu Raya.

Dari hasil penlitian yang dilakukan didapatkan sebagian dari responden yang lama penggunaan suntikan 3 bulan. $>6$ bulan -3 tahun mengalami kenaikan berat badan $1-5 \mathrm{~kg}$ yaitu sebanyak 18 orang $(52,94 \%)$ dan sangat sedikit dari responden yang lama penggunaan suntikan 3 bulan, $>6$ bulan -3 tahun mengalami kenaikan > $5 \mathrm{~kg}$ yaitu 1 orang $(2,94 \%)$, dan sebagian kecil kecil dari responden yang lama penggunaan suntikan 3 bulan $>3$ tahun mengalami kenaikan berat badan 1-5 kg yaitu 13 orang $(38,23 \%)$, serta sangat sedikit dari responden yang lama penggunaan suntikan 3 bulan, > 3 tahun mengalami kenaikan berat badan > $5 \mathrm{~kg}$, yaitu sebnayak 2 orang $(5,88 \%)$.

Menurut Saifuddin (2010) bahwa Depo Medrosiprogesteron asetat (DMPA) yaitu mengandung $150 \mathrm{mg}$ DMPA, yang diberikan setiap 3 bulan dengan cara disuntik intramuskuler (didaerah bokong). Depo Provera ialah 6 alfa medrosiprogesterone yang digunakan untuk tujuan kontrasepsi parenteral, mempunyai efek progestagen yang kuat dan sangat efektif. Obat ini termasuk obat depo. Noristerat juga termasuk dalam golongan kontrasepsi suntikan (Anwar, 2011).

Menurut Irianto (2014) umunya pertambahan berat badan terhadap penggunaan suntikan 3 bulan tidak terlalu besar, bervariasi antara kurang dari $1 \mathrm{~kg}$ sampai $5 \mathrm{~kg}$ dalam tahun pertama. Penggunaan progesterone dapat meningkatkan nafsu makan, efek yang serupa dengan tingginya kadar progesterone dalam kehamilan. Bukti menunjukkan bahwa pertambahan berat badan ini adalah hasil dari peningkatan lemak dan bukan merupakan akibat sekunder dari proses anabolisme atau retensi cairan.

Berkaitan dengan lama penggunaan dengan kenaikan berat badan hal ini sesuai dengan peneltian Ekawati tahun 2010 dengan judul "pengaruh KB suntik DMPA terhadap peningkatan berat badan di BPS Siti Syamsiyah Wonokarto Wonogiri” terhadap 35 akspetor KB DMPA dan 35 akseptor KB bukan DMPA didapatkan hasil pada akseptor KB DMPA 24 responden mengalami kenaikan berat badan dan 11 responden tidak mengalami kenaikan berat badan. Pada akseptor KB bukan DMPA 17 responden mengalami kenaikan berat badan dan 18 responden tidak mengalami kenaikan berat badan. Hasil ini menunjukkan pada akseptor KB DMPA lebih banyak mengalami kenikan berat badan dari pada akseptor bukan $\mathrm{KB}$ DMPA.

Penelitian tentang lama penggunaan kontrasepsi 3 bulan oleh Irianingsih dalam jurnal peneltian Pinasti tahun 2013 dengan judul Pengaruh Penggunaan Kontrasepsi suntikan terhadap peningkatan berat badan dan kenaikan tekanan darah pada akseptor KB di Puskesmas Kecamatan Sokodono kabupaten Stragen. Menunjukkan dari 34 akseptor yang menggunakan KB suntik 3 bulan kurang dari 1 tahun dan 36 akseptor yang menggunakan KB suntik 3 bulan lebih dari 1 tahun. Hasil didapatkan 41 responden dengan peningkatan berat badan dan 29 responden tidak mengalami peningkatan berat badan, jadi akseptor yang menggunakan kontrasepsi suntik 3 bulan lebih 
dari 1 tahun lebih beresiko mengalami peningkatan berat badan. Hal ini juga sesuai dengan penelitian yang dilakukan oleh peneliti bahwa akseptor KB suntik 3 bulan mengalami kenaikan berat badan dalam jangka waktu $>6$ bulan -3 tahun.

Dalam jurnal Griya Husada (2014) dengan judul “ gambaran kejadian peningkatan berat badan pada akspetor KB suntik 3 bulan berdasarkan lamanya pemakaian kontrasepsi” diperoleh hasil akseptor KB suntik 3 bulan yang lama pemakaiannya lebih dari 1 tahun mayoritas mengalami kenaikan berat badan $(89,72 \%)$, disbanding dengan akseptor yang memakai KB suntik 3 bulan kurang dari 1 tahun dengan berat badan stabil atau tetap $(42,86 \%)$, hal ini juga sejalan dengan penelitian yang dilakukan oleh peneliti yaitu dimana sebagian dari responden yang lama penggunaan suntikan KB 3 bulan, > 6 bulan -3 tahun mengalami kenaikan berat badan $1-5 \mathrm{~kg}$ yaitu 18 orang $(52,94 \%)$.

Beksinska et al (2001) dalam jurnal Pratiwi, dengan judul "hubungan antara penggunaan kontrasepsi hormone suntikan DMPA dengan peningkatan Berat badan di Puskesmas Lapai Kota Padang" menyatakan bahwa dari studi-studi peneltian didapatkan peningkatan berat badan akibat penggunaan kontrasepsi DMPA berkaitan dengan peningkatan lemak tubuh dan adanya hubungan dengan regulasi nafsu makan. Salah satu studi menemukan peningkatan nafsu makan yang dilaporkan sendiri oleh wanita yang menggunakan kontrasepsi DMPA setelah 6 bulan. Hal ini dapat dihubungkan dengan kandungan pada DMPA yaitu hormon progesterone, yang dapat merangsang pusat pengendalian nafsu makan di hypothalamus sehingga menyebabkan terjadinya peningkatan nafsu makan.

Hal ini menunjukkan bahwa lama penggunaan terhadap suntikan 3 bulan ini bisa mengakibatkan perubahan atau peningkatan terhadap berat badan akspetor itu sendiri, dan setelah melihat uraian diatas serta berdasarkan uji statistic terhadap lama penggunaan suntikan 3 bulan dengan kenaikan berat badan memiliki nilai korelasi positif yaitu 0,409 , besaran angka korelasi menujukkan bahwa korelasi antara lama penggunaan suntikan 3 bulan dengan kenaikan berat badan yaitu "sedang $(0,40$ 0,599)". Sementara nilai positif mengidentifikasikan pola hubungan antara lama penggunaan suntik 3 bulan adalah searah yaitu semakin lama penggunaan suntik 3 bulan semakin tinggi kenaikan berat badan. Perolehan p hitung $=0,16<0,05$ yang menandakan bahwa hubungan yang terjadi adalah signifikan. Dari nilai korelasi didapatkan bahwa lama penggunaan suntik 3 bulan mempengaruhi kenaikan berat badan sebesar $40 \%$ di RB Mariana Kabupaten Kubu Raya. Penelitian ini dapat digunakan untuk meningkatkan pelayanan dalam memberikan konseling atau informasi terhadap pelayanan Keluarga Berencana (KB) sehingga para akseptor $\mathrm{KB}$ dapat memperoleh informasi yang cukup dan baik tentang Keluarga Berencana khususnya tentang KB suntikan 3 bulan. 


\section{Daftar Pustaka}

Anwar, Mochamad. 2011. Ilmu Kandungan. Jakarta: Bina Pustaka Sarwono Prawirohardjo

Arikunto, Suharsini, 2006. Prosedur Penelitian Suatu Pendekatan Praktik. Jakarta: PT Rineka Cipta

Ari, Wibowo, 2010. Jumlah Penduduk Indonesia.

http//www1.antarnews.com/berita/21641 2/-. Diakses 2016. 04. 02: 17.38

Ekawati, Desi. 2010. KTI Pengaruh KB Suntik DMPA Terhadap Peningkatan Berat Badan. http//eprints.uns.ac.id/134/1/167050309 20101081.pdf.diakses 2016.03.02: 18.45

Hartono, Hanafi. 2010. Keluarga Berencana Dan Kontrasepsi. Jakarta: Pustaka Sinar Harapan.

Haryani, Dewi Dwi. 2010. Pengaruh Frekuensi Kontrasepsi Suntik DMPA Terhadap Kenaikan Berat Badan Pada Akseptor Kontrasepsi Suntik DMPA. http.ie=ISO8859-

$1 \& \mathrm{q}=$ jurnal+dewi+dwi+hariyani+tahun +2010\&btnG. Diakses 14.04.15.42

Husada, Griya. 2014. Gambaran Kejadian Peningkatan Berat Badan Pada Akspetor KB 3 Bulan Berdasarkan Lama Pemakaian Kontrasepsi. http//jurnalgriyahusada.com/awalimages/files/KTI \%20BAB\%201-7.pdf. diakses 2016. 14.04.13.20

Irianto, Koes.2014. Pelayanan Keluarga Berencana. Bandung: Alfabeta

Machfoedz, Ircham. 2014. Metodologi Penelitian Kuantitatif Dan Kualitatif. Yogyakarta: fitramaya

Manuaba, Ida Bagus Gde. 1998. Ilmu Kebidanan Penyakit Kandungan Dan Keluarga Berencana Untuk Pendidikan Bidan. Jakarta: EGC

Medforth, Janet. 2012. Kebidanan Oxford Dari Bidan Untuk Bidan. Jakarta: EGC
Notoatmodjo, Soekidjo. 2002. Metodologi Penelitian Kesehatan. Rineka Cipta: Jakarta

2012. Metodologi peneltian kesehatan. Jakarta: PT Rineka Cipta

Paskalia, 2012. Hubungan Penggunaan KB Suntik Dengan Kejadian Obesitas Pada Wanita Usia 30-50 Tahun Diwilayah Kerja Puskesmas Putussibau Utara Kalimantan Barat. Diakses 2016. 03.02: 19.05

Pinasti, Anisa Putri. 2013. Pengaruh Penggunaan Kontraspesi Suntikan Terhadap Peningkatan Berat Badan Dan Kenaikan Tekanan Darah Pada Akseptor KB Di Puskesmas Kecamatan Sukodono Kabupaten Sragen. https=ISO-8859$1 \& \mathrm{q}=$ naskah+publikasi+oleh+anisa+put ri+pinasti\&btnG.

Diakses 2016.03.02.20.08

Pratiwi, dhania. 2014. Hubungan Antara Penggunaan Kontraspesi Hormonal Suntikan DMPA Dengan Peningkatan Berat Badan Di Puskesmas Lapai Kota Padang. https:hl=id\%ie=ISO-8859$1 \& \mathrm{q}=$ jurnal+dhania + pratiwi. Diakses 2016.04.02.16.23

Profil Kesehatan Provinsi Kalimantan Barat. 2011. Profil Kesehatan. Pontianak: Dinas Kesehatan Provinsi Kalimantan Barat

Pusat Data Dan Informasi Kementerian Kesehatan RI. 2014. Situasi Dan Analisis Keluarga Berencana. Jakarta: Kemenkes RI

Rahmawati, Ita. 2014. Survey Penambahan Berat Badan Pada Akseptor KB Suntik 3 Bulan Di Puskesmas Mayog Kecamatan Mayong Kabupaten Jepara. https:hl=id\%=ISO-8859-

$1 \& \mathrm{q}=$ jurnal+kesehatan + dan + budaya $+\mathrm{al}$ +hikmah+jepara. Diakses 2016. 03.04: 18,44

Saifuddin, Abdul Bari. 2010. Buku Panduan Praktis Pelayanan Kontraspesi. Jakarta: PT Bina Pustaka Sarwono Prawirohardjo 
Sugiyono. 2010. Statistika Untuk Penelitian. Bandung: Alfabeta . 2011.Statistika Untuk Penelitian.

Bandung: Alfabeta

2012. Metode Penelitian Kualitatif dan Kuantitatif dan R dan D. Bandung: Alfabeta

Supriasa, I Dewa Nyoman. 2012. Penilaian Status Gizi. Jakarta: EGC

Suparyanto, 2010. Pengaruh KB Suntik Terhadap Perubahan Berat Badan. http://aadesanjaya.com/blog-archive-

14147-62.html. Diakses 2016. 03.02 : 19.45

Suratun. 2008. Pelayanan Keluarga Berencana Dan Pelayanan Kontrasepsi. Jakarta: Trans Info Media 